\title{
ŚCIERALNOŚĆ BETONOWYCH POSADZEK PRZEMYSŁOWYCH UTWARDZANYCH POWIERZCHNIOWO
}

\begin{abstract}
W artykule przedstawiono wytyczne zawarte w aktualnej literaturze technicznej dotyczące wymagań odnośnie ścieralności betonowych posadzek przemysłowych. Skupiono się na posadzkach wykonywanych w technologii DST. Scharakteryzowano najczęściej stosowane metody badań ścieralności cementowych podkładów podłogowych i związane z nimi klasy odporności na ścieranie. Zebrane informacje mogą być pomocne dla projektantów, inwestorów i wykonawców przy doborze odpowiedniego materiału warstwy wierzchniej posadzki betonowej i opracowywaniu specyfikacji technicznych.
\end{abstract}

Słowa kluczowe: betonowa posadzka przemysłowa, odporność na ścieranie, sucha posypka utwardzająca, badanie ścieralności

\section{Wprowadzenie}

Terminem "posadzki przemysłowe" przyjęto określać wszelkie rodzaje posadzek, które nie służą celom mieszkalnym i nie są wykorzystywane jako nawierzchnie dróg i ulic [1]. Statystyki pokazują, że w ponad $80 \%$ przypadków inwestorzy decydują się na posadzkę na gruncie wykonywaną w technologii powierzchniowego utwardzenia DST (dry shake topping) [2]. Technologia ta polega na rozłożeniu i mechanicznym wtarciu w będący w fazie wiązania beton tzw. mineralnej posypki utwardzającej. Uzyskana w ten sposób wierzchnia warstwa płyty betonowej o grubości 2-3 mm ma przede wszystkim wysoką twardość i wytrzymałość mechaniczną [3], co czyni ją odporną na ścieranie. W warstwie tej uwidacznia się większość wad i usterek posadzki [4]. Przyjmuje się, że powinna ona zapewnić posadzce trwałość bez napraw przez czas nie krótszy niż 25 lat [5], a nawet 50 lat (Eurokod 2). Nadmierne ścieranie betonowych posadzek przemysłowych jest jednym z głównych problemów technicznych występujących w okresie ich eksploatacji, dlatego też w 80 \% przypadków o wyborze ostatecznej technologii wykonania posadzki decyduje kryterium ścieralności

\footnotetext{
${ }^{1}$ Sławomir Słonina, Politechnika Rzeszowska, Wydział Budownictwa, Inżynierii Środowiska i Architektury, Zakład Inżynierii Materiałowej i Technologii Budownictwa, e-mail: sslonina@prz.edu.pl
} 
[6,7]. W artykule zebrano wytyczne zawarte w literaturze technicznej umożliwiające optymalny wybór składnika do wykończenia wierzchniej warstwy posadzki w oparciu o kryterium ścieralności.

\section{Sucha posypka utwardzająca jako podkład podłogowy}

Suche posypki utwardzające to mieszanina wysokiej jakości spoiwa cementowego, specjalnych twardych wypełniaczy o wyselekcjonowanej krzywej uziarnienia oraz dodatków i domieszek polepszających właściwości finalnego produktu [2]. Producenci tego typu produktów (lub materiałów utwardzających) deklarują właściwości techniczne wyrobu zgodnie z wymaganiami normy PN-EN 13813 [8] dla podkładów na bazie cementu. Ujęty w niej zakres badań dla tego typu wyrobów zestawiono w tablicy 1

Tabela 1. Wykaz badań dla podkładów podłogowych na bazie cementu na podstawie [8]

Table 1. Tests for cementitious floor screeds by [8]

\begin{tabular}{|c|c|}
\hline \multicolumn{2}{|c|}{ Rodzaj badań } \\
\hline obowiązkowe & opcjonalne \\
\hline $\begin{array}{l}\text { - wytrzymałość na ściskanie wg PN-EN 13892-2 } \\
\text { - wytrzymałość na zginanie PN-EN 13892-2 } \\
\text { - odporność na ścieranie Böhmego } \\
\text { wg PN-EN 13892-3 lub odporność na ścieranie } \\
\text { BCA wg PN-EN 13892-4 lub odporność na na- } \\
\text { cisk koła wg PN-EN 13892-5* }\end{array}$ & $\begin{array}{l}\text { - twardość powierzchni wg PN-EN 13892-6 } \\
\text { - wytrzymałość na nacisk koła materiału pokryte- } \\
\text { go wykładziną podłogową wg PN-EN 13892-7 } \\
\text { - czas wiązania wg PN-EN 13454-2 } \\
\text { - } \text { skurcz i spęcznienie wg PN-EN 13454-2 lub } \\
\text { PN-EN } 13872 \\
\text { - konsystencja wg PN-EN 13454-2 lub } \\
\text { PN-EN } 12706 \\
\text { - wartość pH wg PN-EN 13454-2 } \\
\text { - } \text { moduł sprężystości wg PN-EN ISO } 178 \\
\text { - przyczepność wg PN-EN 13892-8 } \\
\text { - odporność na uderzenie wg PN-EN ISO } 6272\end{array}$ \\
\hline
\end{tabular}

Ścieralność (abrazja) określona dla jednej z trzech metod badania ścieralności pozwala podlegający ścieraniu wyrób zakwalifikować do jednej z klas przedstawionych w tablicy 2. Próbki przeznaczone do wykonania badań odporności na ścieranie powinny być pobierane, wykonywane i sezonowane zgodnie z wymaganiami normy PN-EN 13892-1 [9]. Przeanalizowanie procedury przygotowania próbek zawartej w tej normie nie pozwala jednak jednoznacznie stwierdzić w jaki sposób należy je przygotować. Warto zwrócić uwagę na następujące zapisy:

- zaprawy należy mieszać dokładnie według zaleceń producenta, z zapewnieniem wymaganej ilości wody lub innego płynu, 
- jeżeli przy dodaniu wody lub innego płynu podany jest ilościowy zakres, to należy przyjąć jego średnią zawartość,

- należy uzyskać konsystencję zaprawy zalecaną przez producenta.

Tabela 2. Klasy odporności na ścieranie podkładów podłogowych na podstawie [8]

Table 2. Abrasion resistance classes for floor screeds by [8]

\begin{tabular}{|c|c|c|c|c|c|}
\hline \multicolumn{2}{|c|}{$\begin{array}{c}\text { Odporność na ścieranie } \\
\text { wg Böhmego }\end{array}$} & \multicolumn{2}{|c|}{ Odporność na ścieranie BCA } & \multicolumn{2}{c|}{$\begin{array}{c}\text { Odporność na ścieranie pod } \\
\text { naciskiem toczącego się koła }\end{array}$} \\
\hline $\begin{array}{c}\text { Maksymalna } \\
\text { wartość abrazji } \\
{\left[\mathbf{c m}^{3} / \mathbf{5 0} \mathbf{~ c m}^{2}\right]}\end{array}$ & $\begin{array}{c}\text { Klasa odpor- } \\
\text { ności } \\
\text { na ścieranie }\end{array}$ & $\begin{array}{c}\text { Maksymalna } \\
\text { wartość abrazji } \\
{[\boldsymbol{\mu m}]}\end{array}$ & $\begin{array}{c}\text { Klasa odpor- } \\
\text { ności } \\
\text { na ścieranie }\end{array}$ & $\begin{array}{c}\text { Maksymalna } \\
\text { wartość abrazji } \\
{\left[\mathbf{c m}^{3}\right]}\end{array}$ & $\begin{array}{c}\text { Klasa odpor- } \\
\text { ności } \\
\text { na ścieranie }\end{array}$ \\
\hline 22 & A22 & & & & \\
15 & A15 & 600 & AR6 & 300 & RWA300 \\
12 & A12 & 400 & AR4 & 100 & RWA100 \\
9 & A9 & 200 & AR2 & 20 & RWA20 \\
6 & A6 & 100 & AR1 & 10 & RWA10 \\
3 & A3 & 50 & AR0,5 & 1 & RWA1 \\
1,5 & A1,5 & & & & \\
\hline
\end{tabular}

Przytoczone wytyczne odnoszą się przede wszystkim do najczęstszego przypadku podkładów podłogowych, czyli wyrobów stosowanych jako gotowe zaprawy. Dlatego też nie uwzględniają one specyfiki aplikacji wyrobów wcieranych w wiążący beton. Przykład suchych posypek utwardzających potwierdza więc zapis zawarty w normie [8]: „Właściwości podkładów podłogowych wykonywanych $\mathrm{w}$ obiekcie budowlanym nie zawsze są porównywalne z odpowiednimi właściwościami uzyskanymi $\mathrm{w}$ warunkach laboratoryjnych, $\mathrm{z}$ uwagi na różnice w przygotowaniu, zagęszczaniu lub sezonowaniu podkładu." Przytoczone normowe zapisy dopuszczają zatem następujące sposoby przygotowania próbek:

1. zmieszanie wyrobu (posypki utwardzającej) ze ściśle określoną ilością wody lub uzyskanie ściśle określonej konsystencji.

2. postępowanie według zaleceń producenta, czyli np. przygotowanie próbek do badania ścieralności w sposób możliwie zbliżony do warunków panujących w obiekcie budowlanym.

Pierwszy sposób przygotowania próbek nie uwzględnia wpływu m.in.:

- mechanicznego wcierania i związanego z tym przemieszania posypki utwardzającej z zaczynem cementowym i drobnym kruszywem znajdującym się w mieszance betonowej,

- ilości wody kształtującej konsystencję posypki utwardzającej w momencie jej wcierania (jest ona trudna do dokładnego ustalenia w warunkach budowy),

- ilości materiału utwardzającego przypadającego na $1 \mathrm{~m}^{2}$ posadzki i ewentualnej nierównomierności jego rozłożenia,

- jakości wykonawstwa,

- składu betonu, z którego wykonano płytę posadzki. 
Przygotowanie próbek według sposobu drugiego wymaga z kolei precyzyjnych uregulowań mających na celu zminimalizowanie lub wręcz wyeliminowanie wpływu wymienionych powyżej czynników. Należy stwierdzić zatem, że kluczowe dla uzyskanych w laboratorium wyników badań m.in. ścieralności, są zalecenia producenta posypki utwardzającej dotyczące przygotowania próbek. Norma [9], z uwagi na swój ogólny charakter, nie określa ani dokładnej ilości wody, którą należy dodać do badanego wyrobu (nie precyzuje konsystencji jaką należy uzyskać w momencie formowanie próbek), ani nie podaje szczegółowych wytycznych dotyczących przygotowania próbek w warunkach zbliżonych do panujących w obiekcie budowlanym. Czyli tak naprawdę pomija niezwykle istotne czynniki mające wpływ na ostateczne wyniki badań. Producenci również pilnie strzegą informacji na ten temat, co powoduje, że wyniki badań laboratoryjnych ścieralności stanowią niejednokrotnie jedynie atut w marketingowym „wyścigu zbrojeń". W efekcie tego często produkty spełniające te same kryteria klas znacząco różnią się od siebie co do składu i mogą zachowywać się odmiennie po wtarciu ich w betonową płytę posadzki. Warto dodać, że w normie [8] nie zawarto żadnych wytycznych łączących warunki eksploatacji posadzki z klasą odporności na ścieranie danego wyrobu do wykończenia warstwy wierzchniej. Taki stan rzeczy z pewnością nie ułatwia dokonania świadomego wyboru inwestorowi, projektantowi, czy też wykonawcy posadzki.

\section{Dobór materiału utwardzającego do warunków eksploatacji posadzki na podstawie krajowych dokumentów normalizacyjnych}

Do problematyki związanej z niszczącym oddziaływaniem ścierania na beton odnosi się norma PN-B-06265 [10], czyli krajowe uzupełnienie do zastąpionej przez PN-EN 206 [11] normy PN-EN 206-1:2003 [12]. Intensywność ścierania ujęta została w postaci klas ekspozycji i powiązana z rodzajem pojazdów eksploatujących posadzkę (tabela 3). Niestety poszczególnym klasom ekspozycji nie przyporządkowano zalecanych poziomów ścieralności warstwy wierzchniej betonu. Do technologii DST w zasadzie odnosi się do jedynie następujący zapis: „Powierzchnia betonu może być uszlachetniona materiałami odpornymi na ścieranie". Wymagania zawarte w PN-B-06265 [10] odnoszą się przede wszystkim do odporności na ścieranie betonu, stąd m.in. zamieszczono wymagania, co do jego składu. W odniesieniu do materiału utwardzającego, który jest wcierany w jego wierzchnią warstwę, a tak zakłada technologia DST, wymagania te nie są do końca uzasadnione względami ekonomicznymi.

Krótkie, ale precyzyjne wytyczne dotyczące wielkości odporności na ścieranie betonu $\mathrm{w}$ zależności od warunków jego pracy zawarto w wycofanej, ale niejednokrotnie przywoływanej $w$ specyfikacjach technicznych normie PN-83/B-06256 [13]. Graniczne wartości ścieralności betonu, określanej na tar- 
Tabela 3. Klasy ekspozycji betonu dla agresji wywołanej ścieraniem na podstawie [10]

Table 3. Exposure classes of concrete for mechanical abrasion by [10]

\begin{tabular}{|c|c|c|c|c|c|c|}
\hline \multirow[b]{2}{*}{$\begin{array}{l}\text { Oznacze- } \\
\text { nie klasy } \\
\text { ekspozycji }\end{array}$} & \multirow[b]{2}{*}{$\begin{array}{l}\text { Zagrożenie } \\
\text { ścieraniem }\end{array}$} & \multirow{2}{*}{$\begin{array}{c}\text { Pojazdy od- } \\
\text { działujące na } \\
\text { posadzkę, na- } \\
\text { wierzchnię }\end{array}$} & \multicolumn{4}{|c|}{$\begin{array}{c}\text { Zalecane wartości graniczne dla składu oraz właściwości } \\
\text { betonu }\end{array}$} \\
\hline & & & $\begin{array}{l}\text { Maksy- } \\
\text { malne w/c }\end{array}$ & $\begin{array}{l}\text { Minimalna } \\
\text { klasa wy- } \\
\text { trzymałości }\end{array}$ & $\begin{array}{c}\text { Minimalna } \\
\text { zawartość } \\
\text { cementu } \\
{\left[\mathrm{kg} / \mathrm{m}^{3}\right]} \\
\end{array}$ & $\begin{array}{c}\text { Inne wymaga- } \\
\text { nia }\end{array}$ \\
\hline XM1 & umiarkowane & $\begin{array}{l}\text { o ogumieniu } \\
\text { pneumatycznym }\end{array}$ & 0,55 & C 30/37 & 300 & - \\
\hline XM2 & silne & $\begin{array}{l}\text { o ogumieniu } \\
\text { pełnym oraz wóz- } \\
\text { ki podnośnikowe } \\
\text { z ogumieniem } \\
\text { elastomerowym } \\
\text { lub na rolkach } \\
\text { stalowych }\end{array}$ & 0,55 & $\mathrm{C} 30 / 37$ & 300 & $\begin{array}{l}\text { pielęgnacja } \\
\text { powierzchni } \\
\text { betonu np. przez } \\
\text { próżniowanie } \\
\text { i wygładzanie } \\
\text { betonu }\end{array}$ \\
\hline XM3 & $\begin{array}{l}\text { ekstremalnie } \\
\text { silne }\end{array}$ & gąsienicowe & 0,45 & C35/45 & 320 & $\begin{array}{l}\text { kruszywo } \\
\text { o dużej odporno- } \\
\text { ści na ścieranie }\end{array}$ \\
\hline
\end{tabular}

czy Böhmego, uzależnione są od rodzaju ruchu zestawiono w tablicy 4. Zawarta w normie [13] definicja utwardzenia powierzchniowego posadzki: ,zwiększenie odporności posadzki na ścieranie kruszywem utwardzającym wciskanym w wierzchnią warstwę świeżo ułożonego betonu, po uprzednim zagęszczeniu tej warstwy" odnosi się do technologii utwardzania stosowanych w okresie obowiązywania normy (1983-2004), a więc nieco odbiegających od stosowanych obecnie. Dlatego też zalecenia dotyczące dopuszczalnego poziomu ścieralności należy potraktować jako poglądowe. Wytycznych dotyczących poziomu ścieralności nie zawarto również $\mathrm{w}$ wydanych w ostatnich latach przez Instytut Techniki Budowlanej poradnikach [14-15]. W publikacjach tych na temat ścieralności posadzki zamieszczono jedynie krótkie zapisy o:

- konieczności uszczegółowienia wymaganej ścieralności w projekcie posadzki,

- możliwości ewentualnego (wykonywanego na żądanie inwestora) pobierania próbek do badania ścieralności na tarczy Böhmego.

Tabela 4. Limity ścieralności betonu odpornego na ścieranie na podstawie [13]

Table 4. Abrasion resistance limits for concrete resistant to abrasion by [13]

\begin{tabular}{|l|l|c|}
\hline \multicolumn{1}{|c|}{$\begin{array}{c}\text { Rodzaj } \\
\text { ruchu }\end{array}$} & \multicolumn{1}{|c|}{ Charakterystyka ruchu } & $\begin{array}{c}\text { Maksymalna wartość } \\
\text { ścieralności wg } \\
\text { Böhmego }\left[\mathbf{c m}^{\mathbf{3}} / \mathbf{5 0} \mathbf{~ c m}^{\mathbf{2}}\right]\end{array}$ \\
\hline $\begin{array}{l}\text { ciężki } \\
\text { i duży }\end{array}$ & $\begin{array}{l}\text { ruch sprzętu ciężkiego i wózków nieogumionych, } \\
\text { stale występujące duże obciążenia dynamiczne } \\
\text { i statyczne, częste uderzenia }\end{array}$ & 12,5 \\
\hline średni & $\begin{array}{l}\text { duży ruch ludzi, ruch lekkich wózków ogumionych, } \\
\text { niewielkie obciążenia dynamiczne i statyczne }\end{array}$ & 15 \\
\hline
\end{tabular}




\section{Dobór materiału utwardzającego do warunków eksploatacji posadzki na podstawie wytycznych literatury technicznej}

W ostatniej dekadzie ubiegłego stulecia oraz na początku obecnego opublikowano wiele broszur, będących zwykle tłumaczeniami na język polski i przedrukami opisującymi materiały utwardzające stosowane do wykończenia wierzchniej warstwy posadzek [16]. Artykuły w czasopismach technicznych wznacznej mierze również służyły raczej popularyzowaniu działalności dostawców konkretnych technologii, aniżeli merytorycznej inżynierskiej dyskusji. Spośród publikacji z tego okresu na uwagę zasługują publikacje autorów związanych z firmami Bautech oraz Sika. W tablicy 5 zestawiono zalecenia zawarte w publikacji [5].

Tabela 5. Limity ścieralności w zależności od intensywności ruchu na podstawie [5]

Table 5. Abrasion resistance limits depending on traffic intensity by [5]

\begin{tabular}{|l|c|}
\hline \multicolumn{1}{|c|}{ Intensywność ruchu } & $\begin{array}{c}\text { Maksymalny poziom ścieralności } \\
\text { wg Böhmego }\left[\mathbf{c m}^{\mathbf{3}} / \mathbf{5 0} \mathbf{~ c m}^{\mathbf{2}}\right]\end{array}$ \\
\hline najczęściej spotykana (przeciętna) & $\leq 5$ \\
\hline szczególnie wysoka & $\leq 3 \mathrm{lub} \leq 2$ \\
\hline
\end{tabular}

Podobne zalecenia znajdują się w pochodzących z tamtego okresu materiałach informacyjnych firmy Addiment (aktualnie Sika Poland) [17]. Zawarto w nich m.in. informacje na temat:

- wielkości ścieralności suchej posypki przy zastosowaniu jej w ilości $4 \div 7 \mathrm{~kg} / \mathrm{m}^{2}$ utwardzanej posadzki (ścieralność wg Böhmego $3 \div 8 \mathrm{~cm}^{3} / 50 \mathrm{~cm}^{2}$ ),

- posypek o niskiej ścieralności (ścieralność wg Böhmego $<4 \mathrm{~cm}^{3} / 50 \mathrm{~cm}^{2}$ ),

- przypadków zastosowania posypki o bardzo niskiej ścieralności, np. $<3 \mathrm{~cm}^{3} / 50 \mathrm{~cm}^{2}$ (szczególnie wysokie natężenia ruchu, pojazdy o kołach czy gąsienicach metalowych).

W pracy [18] zaprezentowana została klasyfikacja suchych posypek utwardzających przedstawiona w tablicy 6 . Odnosi się ona wprawdzie bezpośrednio do oferty dostawcy technologii (firma Bautech), ale uznać ją można jako udaną próbę podziału suchych posypek utwardzających ze względu na skład i związany z nim poziom ścieralności badany za pomocą tarczy Böhmego.

W ostatnich latach coraz powszechniej do określania ścieralności posadzki używana jest metoda BCA (British Cement Association). Wywodzi się ona z norm brytyjskich. Polega ona na pomiarze, na powierzchni wykonanej posadzki, głębokości śladu powstałego po 2850 obrotach trzech stalowych, hartowanych kół przymocowanych do urządzenia badawczego, wirujących z prędkością $180 \mathrm{obr} . / m i n u t e ̨$. Przeprowadzenie pojedynczego badania tą metodą zajmuje kilkanaście minut. Ponadto, można je wykonać $\mathrm{w}$ warunkach budowy przy możliwie minimalnym uszkodzeniu powierzchni posadzki. Te niewątpliwe zalety powodują, że metoda ta jest coraz częściej stosowana, zaś jego wyniki niejedno- 
Tabela 6. Klasyfikacja suchych posypek utwardzających na podstawie [18] i [19]

Table. 6. Classification of dry shake toppings by [18] i [19]

\begin{tabular}{|c|c|c|c|c|c|}
\hline $\begin{array}{c}\text { Rodzaj } \\
\text { utwardzacza }\end{array}$ & $\begin{array}{c}\text { Wytrzymałość } \\
\text { na ściskanie } \\
\text { [MPa] }\end{array}$ & $\begin{array}{c}\text { Wytrzymałość } \\
\text { na zginanie } \\
\text { [MPa] }\end{array}$ & $\begin{array}{c}\text { Dozowanie } \\
{\left[\mathrm{kg} / \mathrm{m}^{2}\right]}\end{array}$ & $\begin{array}{c}\text { Ścieralność wg } \\
\text { Böhmego } \\
{\left[\mathrm{cm}^{3} / 50 \mathrm{~cm}^{2}\right]}\end{array}$ & $\begin{array}{l}\text { Przykład zasto- } \\
\text { sowania (klasa } \\
\text { ekspozycji } \\
\text { wg [10]) }\end{array}$ \\
\hline mineralny & $>67$ & $>11$ & $4 \div 5$ & 4,5 & \multirow{2}{*}{$\begin{array}{l}\text { obiekty handlowe, } \\
\text { warsztaty, garaże } \\
\text { i magazyny (XM1 } \\
\text { i XM2) }\end{array}$} \\
\hline semimetaliczny & $>70$ & $>13$ & $4 \div 5$ & 3,9 & \\
\hline metaliczny & $>70$ & $>14$ & $5 \div 7$ & 2,3 & $\begin{array}{l}\text { przemysł ciężki, } \\
\text { zakłady produk- } \\
\text { cyjne i elektrow- } \\
\text { nie (XM3) }\end{array}$ \\
\hline
\end{tabular}

krotnie warunkują odbiór nowo wykonanej posadzki. Procedura badawcza w metodzie BCA, w odróżnieniu od metody Böhmego, symuluje długoterminowe obciążenia mechaniczne posadzki w sposób przyspieszony [20]. Wynik badania obrazuje zużycie posadzki po 25 latach użytkowania [21]. Coraz większa liczba producentów posypek utwardzających deklaruje jedynie ścieralność określoną metodą BCA, co nie ułatwia np. projektantowi doboru materiału utwardzającego odpowiedniego do warunków użytkowania. Użyteczna w tym zakresie jest norma brytyjska BS 8204-2:2002 [22], w której poszczególnym klasom odporności na ścieranie przyporządkowano warunki użytkowania i odpowiadające im limity testów ścieralności metodą BCA (tabela 7).

Tabela 7. Klasy odporności na ścieranie metodą BCA na podstawie [21]

Table 7. Abrasion resistance classes for BCA method by [21]

\begin{tabular}{|l|l|l|l|c|}
\hline $\begin{array}{c}\text { Klasa od- } \\
\text { porności na } \\
\text { ścieranie }\end{array}$ & $\begin{array}{l}\text { Odporność } \\
\text { na ścieranie }\end{array}$ & Warunki użytkowania & Typowe zastosowania & $\begin{array}{c}\text { Limity } \\
\text { dla testów } \\
\text { [mm] }\end{array}$ \\
\hline $\begin{array}{l}\text { AR 0,5 } \\
\text { specjalna }\end{array}$ & $\begin{array}{l}\text { ekstremalnie } \\
\text { wysoka }\end{array}$ & $\begin{array}{l}\text { nacisk kół stalowych lub neo- } \\
\text { prenowych, odporność na za- } \\
\text { drapania, ścieranie w wyniku } \\
\text { przesuwania twardych przed- } \\
\text { miotów }\end{array}$ & $\begin{array}{l}\text { miejsca przeładunku, od- } \\
\text { lewnie, inne miejsca szcze- } \\
\text { gólnie narażone na uszko- } \\
\text { dzenia }\end{array}$ & 0,05 \\
\hline AR1 & $\begin{array}{l}\text { bardzo wyso- } \\
\text { ka }\end{array}$ & $\begin{array}{l}\text { ruch wózków na twardych ko- } \\
\text { łach stalowych, neoprenowych, } \\
\text { miejsca narażone na występo- } \\
\text { wanie materiałów ścierających }\end{array}$ & $\begin{array}{l}\text { obiekty produkcyjne, ma- } \\
\text { gazyny, hale logistyczne }\end{array}$ & 0,10 \\
\hline AR2 & wysoka & ruch kół neoprenowych & $\begin{array}{l}\text { mało obciążone obiekty } \\
\text { produkcyjne, magazynowe, gumowych }\end{array}$ & 0,40 \\
\hline AR3 & średnia & handlowe, rekreacyjne & 0,20 \\
\hline
\end{tabular}




\section{Podsumowanie}

Właściwy dobór materiału utwardzającego do wykończenia posadzki nie jest możliwy bez uprzedniego precyzyjnego sformułowania szczegółowych warunków jej eksploatacji (cyklu życia).

Zdaniem autora, zebrane w niniejszej pracy informacje umożliwią inwestorowi, projektantowi, czy też wykonawcy posadzki świadomy dobór materiału utwardzającego do wykończenia warstwy wierzchniej posadzki w technologii DST. Pozwoli to uniknąć wielu niepotrzebnych konfliktów w trójkącie inwestor - projektant -wykonawca, w których niejednokrotnie uczestniczy dostawca betonu jako czwarta strona. Może się też przyczyni do wykonywania posadzek o ścieralności dostosowanej do sposobu użytkowania.

\section{Literatura}

[1] Jasiczak J.: Posadzki przemysłowe. Materiały, technologie, projektowanie, naprawy, Addiment Polska Sp. z o.o., Poznań 2001.

[2] Gielnik K.: Czynniki kształtujące odporność na ścieranie betonowych posadzek przemysłowych, Seminarium naukowo-techniczne „Podłogi przemysłowe” 06.10.2009, s. 90-97.

[3] Starosolski W.: Konstrukcje żelbetowe według Eurokodu 2 i norm związanych, tom III, rozdział 6 Posadzki przemysłowe, Wydawnictwo Naukowe PWN, Warszawa 2013.

[4] Ryżyński W.: Utwardzenie powierzchniowe posadzki betonowej - cz. II, Inżynier Budownictwa, nr 3, 2015, s. 118-122.

[5] Karwacki J.: Podłogi przemysłowe, Polski Cement, kwiecień - czerwiec 2001, s. 32-34.

[6] Horszczaruk E.: Odporność na ścieranie betonowych posadzek przemysłowych, Materiały Budowlane, nr 9, 2014, s. 4-6.

[7] Karwacki J.: Betonowe nawierzchnie przemysłowe nowej generacji, Przegląd Budowlany nr 1, 1997, s. 4-7.

[8] PN-EN 13813 Podkłady podłogowe oraz materiały do ich wykonania. Materiały Właściwości i wymagania.

[9] PN-EN 13892-1 Metody badania materiałów na podkłady podłogowe Część 1: Pobieranie, wykonywanie i przechowywanie próbek do badań.

[10] PN-B-06265 Krajowe uzupełnienia PN-EN 206-1:2003 Beton Część1: Wymagania, właściwości, produkcja i zgodność.

[11] PN-EN 206 Beton Wymagania, właściwości, produkcja i zgodność.

[12] PN-EN 206-1:2003 Beton Część 1: Wymagania, właściwości, produkcja i zgodność.

[13] PN-83 B-06256 Beton odporny na ścieranie.

[14] Sokalska A., Suchan M., Ściślewski Z.: Warunki Techniczne Wykonania i Odbioru Robót Budowlanych, część B. Roboty Wykończeniowe. Zeszyt 3. Posadzki mineralne i żywiczne. Instytut Techniki Budowlanej, Warszawa 2013. 
[15] Warunki Techniczne Wykonania i Odbioru Robót Budowlanych, część B. Roboty Wykończeniowe. Zeszyt 8. Posadzki betonowe utwardzone powierzchniowo preparatami proszkowymi. Instytut Techniki Budowlanej, Warszawa 2010.

[16] Hajduk P.: Projektowanie podłóg przemysłowych. Wydawnictwo Naukowe PWN, Warszawa 2013.

[17] Materiały firmy Addiment.

[18] Latoszek P.: Powierzchniowo utwardzane monolityczne nawierzchnie przemysłowe z fibrobetonów, Konferencja „Dni Betonu” 2004.

[19] Ryżyński W.: Utwardzenie powierzchniowe posadzki betonowej - cz. I, Inżynier Budownictwa, nr 2, 2015, s. 54-62.

[20] Materiały firmy Panbex.

[21] Materiały firmy Formatiq.

[22] BS 8204-2:2002 Screeds, bases and in situ floorings. Concrete wearing surfaces. Code of practice.

\section{ABRASION RESISTANCE OF CONCRETE INDUSTRIAL DST FLOORS}

\section{S u m m a r y}

The following paper presents the most important guidelines featured in the current technical literature about requirements on abrasion resistance of concrete industrial DST floors. The most popular abrasion test methods and abrasion resistance classes for cementitious floor screeds were described. The collected information may be helpful for designers, investors and contractors in selecting the proper material for the concrete floor topping and writing technical specifications.

Keywords: concrete industrial floor, abrasion resistance, DST (dry shake topping), abrasion test

Przestano do redakcji: 16.01.2017 $r$.

Przyjęto do druku: 31.03.2017 r. 